\begin{tabular}{|l|l|l|}
\hline \multicolumn{2}{|c|}{ PublisherInfo } \\
\hline \hline PublisherName & $:$ & BioMed Central \\
\hline \hline PublisherLocation & $:$ & London \\
\hline \hline PublisherImprintName & $:$ & BioMed Central \\
\hline
\end{tabular}

\title{
Tumor necrosis factor response enhanced by hemoglobin infusion
}

\begin{tabular}{|l|l|l||}
\hline \multicolumn{2}{|c||}{ ArticleInfo } \\
\hline \hline ArticleID & $:$ & 4075 \\
\hline \hline ArticleDOI & $:$ & $10.1186 /$ ccf-1999-1082 \\
\hline \hline ArticleCitationID & $:$ & 1082 \\
\hline \hline ArticleSequenceNumber & $:$ & 12 \\
\hline \hline ArticleCategory & $:$ & Paper Report \\
\hline ArticleFirstPage & $:$ & 1 \\
\hline \hline ArticleLastPage & $:$ & 3 \\
\hline \hline & & RegistrationDate : 1999-7-23 \\
\hline ArticleHistory & $:$ & OnlineDate \\
\hline \hline ArticleCopyright & $:$ & Current Science Ltd1999-7-23 \\
\hline \hline ArticleGrants & $:$ & \\
\hline \hline ArticleContext & $:$ & 130541111 \\
\hline \hline
\end{tabular}




\section{Keywords}

Animal model, bacterial lipopolysaccharide, endotoxin, hemoglobin, monocyte/macrophage system, reticuloendothelial cell system, tumor necrosis factor

\section{Comments}

While hemoglobin solutions are generally well tolerated in trials in healthy human subjects, this study raises concerns for the use of such solutions in the intensive therapy unit population who are often septic or may become septic. The illustration of a possible mechanism involving TNF and other cytokines gives a biological plausibilty to these observations. Obviously, further studies defining the precise role of TNF in this response are needed. This study has important implications for the future development of hemoglobin solutions.

\section{Introduction}

Recent evidence suggests that infusion of red cells may not be entirely beneficial to all patients. This has been instrumental in the search for an alternative oxygen carrying solution. Many of the solutions under trial are cell-free hemoglobin solutions. Such solutions in animal studies are beneficial in the treatment of hemorrhage but some studies have demonstrated potential toxicity when such solutions interact with infectious agents. By extrapolating these results to humans, there may be increased mortality in patients who are either septic when they receive, or who become septic after receiving, such hemoglobin solutions. It has also been demonstrated that hemoglobin in animal studies increases lethality from bacterial endotoxin [lipopolysaccharide (LPS)].

\section{Aims}

The study aimed to examine whether cell-free hemoglobin augments the inflammatory cascade, as detected by the production of tumor necrosis factor (TNF), elicited by bacterial endotoxin (LPS). 


\section{Methods}

This in vivo study used female Swiss Webster mice. The hemoglobin solution used consisted of $7.5 \mathrm{~g} /$ dl hemoglobin in Ringer's acetate. The mice were injected intraperitoneally with LPS, with the hemoglobin solution infused intravenously either 8 to $10 \mathrm{~h}$ before, at the same time as, or $10 \mathrm{~h}$ after LPS injection. Control animals received LPS but the intravenous solution was $0.9 \%$ saline, so that all animals received the same fluid load. Blood was taken at time intervals and analysed for TNF. Kupffer cells, peripheral blood mononuclear cells and peritoneal macrophages were isolated from the animals and their response to LPS ex vivo analysed.

\section{Results}

If the mice were given the infusion of hemoglobin either $10 \mathrm{~h}$ before or at the same time as the intraperitoneal LPS, they had a peak of plasma TNF that was greater than the control mice who were given LPS only. The Kupffer cells, from the mice who received hemoglobin $10 \mathrm{~h}$ before the LPS, produced more TNF in response to LPS in vitro than the cells from the control mice. There was a trend (not statistically significant) toward greater TNF production from peripheral blood mononuclear cells in vitroin those cells obtained from the mice treated with hemoglobin solution. There was no increased sensitivity to LPS in the peritoneal macrophages removed from mice that had received hemoglobin solution.

\section{Discussion}

In this study, intravenous hemoglobin increased the sensitivity of hepatic macrophages to subsequent stimulation by LPS. This appears to involve the inflammatory cascade as shown by the upregulation of TNF from these particular cells. The authors suggest that this effect may contribute to the increased mortality that has been shown in animals that have received both hemoglobin solution and LPS. This increased mortality may involve a perturbation in monocytes/macrophages that result in increased sensitivity to LPS. The precise role for augmented production of TNF resulting in increased mortality is still unclear.

\section{References}

1. Su D, Roth RI, Levin J: Hemoglobin infusion augments the tumor necrosis factor response to bacterial endotoxin (lipopolysaccharide) in mice. Crit Care Med. 1999, 27: 771-778. 